\title{
DESIGN, CONSTRUCTION AND EVALUATION OF A VERTICAL PLATE MAIZE SEED PLANTER FOR GARDENS AND SMALL HOLDER FARMERS
}

\author{
O. A. Ani ${ }^{1}{ }^{*}$, B. B. Uzoejinwa ${ }^{2}$ and N. F. Anochili ${ }^{3}$ \\ 1,2,3 Dept. of Agricultural and Bioresources EnG'G, University of NigERIA, NSUKKA, ENUGU STATE. NiGERIA \\ E-mail addresses:1'ozoemena.ani@unn.edu.ng,2benjamin.uzoejinwa@unn.edu.ng \\ 3 nnamdi.anochili@unn.edu.ng
}

\begin{abstract}
Metering mechanism is a key component of planters that directly affect crop development and yield based on the performance of the particular design. Vertical plate metering device is intended to minimize seed damage during planting while improving metering efficiency and field capacity. A vertical plate maize seed planter which is adapted for gardens and small holder farmers cultivating less than two hectares has been designed, constructed and tested. The major components of the planter are hopper, seed metering mechanism, seed chute, furrow opener, furrow closer and wheels. Field test was carried out to determine the field efficiency, effective field capacity, metering efficiency and time required to plant one hectare of farmland. Results showed that the planter has a metering efficiency of $88.94 \%$, effective field capacity of $0.27 \mathrm{ha} / \mathrm{hr}$ and field efficiency of $71.86 \%$. The time required to plant one hectare of farmland was determined as 3.7 hours. The average number of seeds planted per stand was determined as two and percentage seed damage was determined as $1.71 \%$. This planter is considered economical, requiring no special skill to operate and can be adopted for maize planting by small holder farmers.
\end{abstract}

\section{Keywords: planter, design of planter, seed planter, small holder farmer}

\section{INTRODUCTION}

Maize sometimes referred to as corn is a popular staple food in Nigeria as well as an important raw material for industries. It is processed in different forms as livestock feed. Maize is an important source of carbohydrate, protein, iron, vitamin B, and minerals. Nigerians and other Africans consume maize as a starchy base in a wide variety of porridges, pastes, grits, and beer. Fresh maize is eaten parched [1] baked, roasted or boiled. Despite previous efforts, maize and other seed planting in Nigeria is still largely traditional and manual, characterized by drudgery and time wasting. In large farms, tractor drawn planters are usually preferred, however manually powered planters are considered more economical and suitable for gardens and small holder farmers cultivating less than two hectares of land.

In Nigeria, various types of planters have been designed and developed using different approaches. Olajide and Manuwa [2] designed, fabricated and tested a low-cost grain planter capable of planting three types of grains- maize, soybean and cowpea. The planter had an average field capacity of $0.36 \mathrm{ha} / \mathrm{hr}$ and efficiency of $71 \%$ with a percentage seed damage of $2.58 \%$, spacing of $50.2 \mathrm{~cm}$ and an average depth of $4.28 \mathrm{~cm}$. Ikechukwu et al. [3] designed and fabricated a manually operated single row maize planter for garden use and the field test results showed that the planter had a planting capacity of 0.0486 hectare/hr. Oduma et al. [4] also developed and tested a manually operated cowpea precision planter. Test results showed minimal seed damage with good performance for cowpea, a field efficiency of $71.71 \%$ and an average field capacity of $0.260 \mathrm{ha} / \mathrm{hr}$. Bashiri et al. [5] developed and tested a prototype simple hand planter for maize. Test results showed that the planter has a metering efficiency and accuracy of $96 \%$ and 58\% respectively with a field capacity of $0.5 \mathrm{ha} / \mathrm{hr}$ as against $22 \mathrm{hr}$ per hectare if one person is to work. Adisa and Braide [6] developed template row crop planter with a planting rate of $0.20 \mathrm{ha} / \mathrm{h}$. Gupta and Herwanto [7] also designed and developed a direct paddy seeder to match a two- wheel tractor. The machine had a field capacity of $0.5 \mathrm{ha} / \mathrm{hr}$ at a forward 
speed of $0.81 \mathrm{~m} / \mathrm{s}$. Kumar et al. [8] developed a manually operated seeding attachment for an animal drawn cultivator with a seed rate of $43.2 \mathrm{~kg} / \mathrm{hr}$ and field capacity of $0.282 \mathrm{ha} / \mathrm{hr}$. Tests showed minimal seed damage with good performance for wheat and barley. Metering mechanism is a key component of planters that directly affect crop development and yield based on the performance of the particular design. A wide range of seed metering devices exist, but most can be classified as either precision or mass flow type, depending primarily on their principle of operation and the resulting planting pattern [9]. Mass flow types do not meter individual seeds but rather a consistent volume of seeds per unit of time to give the average desired seed spacing. They are therefore used for crops that are usually planted at higher seeding densities (150 -1500seeds $/ \mathrm{m}^{2}$ ); planted in relatively narrow rows $(80-350 \mathrm{~mm})$; and for crops (such as cereal grains and grass pastures) that can tolerate considerable variation in both seeding rate and uniformity of seed spacing without a significant loss in yield $[9,10]$. Mass flow seed metering systems are used on planters generally referred to as broadcast, drill and air seeders and can be broadly classified as either stationary opening, external force feed (fluted and peg/studded rollers) and internal force feed (double run) types [9]. Precision seed metering systems are generally used on row crop planters and for metering single seeds [11]. Depending on the design and/or shape of the principal moving element that enables selection of single seeds from the seed lot, precision metering devices can be broadly classified as plate, belt, disc, drum or finger types [12, 13]. Plate planters are those that principally use a moving plate with indents, i.e. holes, cells or cups, around its periphery and metering performance is generally highly dependent on matching the size (length, breadth and thickness) of the indents to the size of the seed. Plate meters can be sub-classified as horizontal plate, inclined plate or vertical plate types [9]. Previous research effort suggested that plate metering system would be suitable for maize seeds [12]. From the foregoing, it is evident that in Nigeria, various types of planters have been designed and developed using different approaches; however each of them has its own advantages and limitations as may be noticed from the discussion. This particular design aims at investigating the effectiveness of vertical plate metering mechanism specifically targeted at maize seed planting. Vertical plate metering device is intended to minimize seed damage during planting while improving metering efficiency and field capacity. It is therefore another contribution to the numerous efforts being made towards mechanizing maize seed planting in Nigeria through indigenous efforts. According to [14] the basic objective of planting operation is to put the seed and fertilizer in rows at desired depth and seed to seed spacing, cover the seeds with soil and provide proper compaction over the seed. Also Fenner [15] stated that for optimum yields to be achieved, a seed planter with high effectiveness and efficiency and also precision has to be used to carry out the planting operation. Research has shown that many growers could improve their yields by just improving on the performance of their planters [16]. This work therefore aims at improving the metering efficiency and field capacity of maize seed planting while minimizing seed damage through the use of a vertical plate push type planter. The specific objective is therefore to design, construct and test a vertical plate maize seed planter for gardens and small holder farmers.

\section{MATERIALS AND METHODS}

\subsection{Design Considerations and Mode of Operation}

The planter is designed to serve as an intermediate technology between the hand tools and the tractor drawn multi-row planters; mainly for small holder farmers cultivating less than two hectares of land. This is necessary considering that more than half of the farming population in the country cannot afford either to buy or hire tractor drawn planting machinery, given their level of income and size of farm. The planter is intended to minimize drudgery by eliminating continuous bending down and standing up, time wasting, hand method of seed metering, furrow opening and closing and fatigue that generally characterize traditional seed planting by most Nigerian farmers. The design and material selection also ensured that the machine will be easy to construct, affordable to the target end users, with most of the component parts made with locally available materials, and low technology requiring little or no training for operation and maintenance. The planter is a single row push type. To operate it, seeds are poured into the hopper; the planter is then positioned at the desired starting point, and pushed along the row. About two seeds are picked up by the metering plate and introduced into the chute. The furrow opener continuously opens the soil and the seeds metered into the chute fall into the opened 
furrow which are simultaneously closed by the furrow closer. As the planter is pushed along the row, it plants continuously at $30 \mathrm{~cm}$ intra row spacing, until the seeds in the hopper will finish to a level requiring refilling the hopper.

\subsection{Description of Components, Design Analysis and Material Selections}

Detailed description of the component parts of the planter, design analysis and material selections are presented in this section.

2.2.1 Seed metering mechanism: The metering mechanism is a major component in a planter. It picks required number of seeds and delivers them into the soil through the chute at required depths created by furrow openers. Therefore the design must consider the size of the seed, the intra and inter row spacing for each seed, which usually differs from one crop to another, and for different desired plant populations and for different geographical locations. According to [17], seed plate thickness should be between the ranges of 3 to $6 \mathrm{~mm}$ to enable easy picking up of seeds and also to avoid damage of the seeds. In this design, the metering mechanism is a mild steel plate of $100 \mathrm{~mm}$ diameter and $5 \mathrm{~mm}$ thickness with three equally spaced cells near and flushing with the circumference of the plate. The cells are designed to pick an average of two maize seeds and drop them at intra row spacing of $30 \mathrm{~cm}$. The plate is attached vertically on a horizontal shaft driven by the front wheel through a belt and pulley transmission. The belt and pulley drive mechanism consists of two pulleys and a belt used to drive the seed plate. One pulley is attached to the front wheel of the planter which is the driving wheel while the other is attached to the hopper which drives the seed plate to meter the seeds.

2.2.2 Seed chute: The chute is a tube through which the seeds metered out by the cells travel before they are deposited into the furrow. The seed chute is located on the outer part of the hopper by the side on which the vertical seed plate is attached. The material used for the design is a cylindrical funnel made of mild steel pipe with a diameter of $32 \mathrm{~mm}$.

2.2.3 Furrow opener: Furrow openers open the soil where seeds metered out and falling through the chute will be dropped into and covered. Soil type, soil condition, angle of attack and depth of planting should be considered in designing furrow openers. The type of furrow opener used for this design is the adjustable 'shovel type' furrow opener which gives a ' $v$ ' shaped furrow opening and is suitable because it cuts and displaces the soil sideways for easy planting [17]. The adjustable furrow opener permits planting at each variety's ideal ground depth. The material used for the furrow opener design was mild steel angle iron of $2 \mathrm{~mm}$ thickness.

2.2.4 Furrow closer: The furrow closer was also designed to be adjustable. It was designed to allow for proper covering and compaction of the soil over the seeds in the furrows. The material used for the design was mild steel angle iron of $2 \mathrm{~mm}$ thickness, folded into a sort of shovel and positioned at the back of the chute.

2.2.5 The frame : The frame is like the chasis for the planter, it forms the platform on which other components are fixed. The material of the main frame was selected based on achieving a reasonable weight and required strength and reliability and readily available material. In this work, mild steel angle iron of $30.2 \mathrm{~mm}$ by $30.2 \mathrm{~mm}$ by $3 \mathrm{~mm}$ thickness was used. Angle iron which is made of carbon steel has high strength properties and is used for general engineering purposes[18]; also it has good weld properties and does not easily break off. The particular angle iron selected was considered less heavy than other dimensions while still having required strength properties. The length of the main frame used in this design is $900 \mathrm{~mm}$.

2.2.6 The front wheel: According to [19], wheels of larger diameters are to reduce rolling resistance especially in the case of traction wheels. In this work, the front wheel is designed to be a traction wheel to enhance movement on loose soils. It is made of a $6 \mathrm{~mm}$ thick mild steel plate cut out into $80 \mathrm{~mm}$ width and folded into a circle of $400 \mathrm{~mm}$ diameter. Small pieces of $\mathrm{v}$-shaped metals are attached alternately throughout the circumference of the wheel to provide lugs for effective gripping of the ground surface. The wheel has $3 \mathrm{~mm}$ thick and $20 \mathrm{~mm}$ wide flat bars as spokes which are welded to a hub containing a bearing. The front wheel provides drive for the metering mechanism through a belt and pulley system.

2.2.7 The rear wheel: The rear wheel is the driven wheel. It is a rigid rubber wheel of $300 \mathrm{~mm}$ diameter to 
enhance stability and maneuverability. Pneumatic tires could also be used in place of rigid tires. Rubber tires are more suitable for withstanding vertical deflection. Tire rolling resistance decreases with increase in pressure on the ground surface. As the pressure increases, the tire holds its shape more firmly and vertical deflection decreases. The deformation of rubber is less compared to that in a tire with lower pressure. There are standard wheel sizes for equipment similar to wheel barrows and they range from 250 to $300 \mathrm{~mm}$ in diameter [19]. These wheels have pressure ranges of 10 to $16 \mathrm{psi}$ and could be used for this design.

2.2.8 The handle: The handle is used to provide the push force from a human operator to move the planter from point to point during planting operation. The handle is adjustable to take care of differences in height of operators. Angle iron was chosen for the handle because of its high strength and rigidity properties to prevent bending or breaking during operation. The $30.2 \mathrm{~mm} \times 30.2 \mathrm{~mm} \times 3 \mathrm{~mm}$ dimension was selected because of weight considerations to enable ease of operation [18].

2.2.9 Hopper design: The hopper is trapezoidal on the inside and constructed to have an external cuboidal shape. The shape is informed by the nature and location of the seed metering mechanism as shown in Figure 1.To ensure free flow of seeds, the slope of the hopper was fixed at $30^{\circ}$, which is modestly higher than the average angle of repose of the seeds. The material used for the hopper design was $3 \mathrm{~mm}$ thick mild steel sheet metal. The volume of the hopper was determined as $4975.8 \mathrm{~cm}^{3}$. The weight of hopper material was determined as follows:

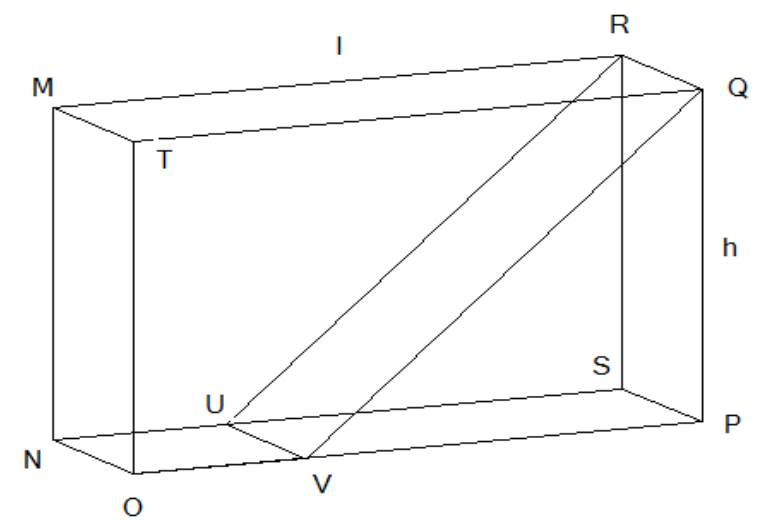

Figure 1 Schematic diagram of the hopper

From the Figure 1 above, the surface area of the hopper material is given in equation (1).

$$
\begin{gathered}
\mathrm{SA}_{\mathrm{h}}=[2\{(\overline{\mathrm{MT}} \times \overline{\mathrm{MN}})+\overline{(\mathrm{TQ}} \times \overline{\mathrm{QP}})+(\overline{\mathrm{MR}} \\
\times \overline{\mathrm{RQ}})\}+(\overline{\mathrm{UV}} \times \overline{\mathrm{VQ}})] \\
\mathrm{V}_{\mathrm{hm}}=\mathrm{SA}_{\mathrm{h}} \times \mathrm{t}_{\mathrm{m}} \\
\mathrm{M}_{\mathrm{hm}}=\mathrm{V}_{\mathrm{hm}} \times \rho_{\mathrm{hm}}
\end{gathered}
$$

In (2) and (3), $V_{\mathrm{hm}}$ is the volume of hopper material $\left(m^{3}\right), t_{h m}$ is the thickness of hopper material $(m), M_{h m}$ is the mass of hopper material $(\mathrm{Kg})$ and $\rho_{\mathrm{hm}}$ is density of the hopper material $\left(\mathrm{Kg} / \mathrm{m}^{3}\right)$.

Thus, the weight of the hopper material $\left(\mathrm{W}_{\mathrm{hm}}\right)$ was determined as $62.10 \mathrm{~N}$ using equation (4).

$$
\mathrm{W}_{\mathrm{hm}}=\mathrm{H}_{\mathrm{hm}} \times \mathrm{g}
$$

\subsubsection{Determination of the weight of the main frame} material: From Figure 2, the following relationships exist from similarity principles of plane geometry. The curved surface area of the cylindrical section of the main frame $\left(\mathrm{CSA}_{\mathrm{m}}\right)$ is estimated using:

$$
\mathrm{CSA}_{\mathrm{m}}=2 \pi \mathrm{rl}+2 \pi \mathrm{r}^{2}
$$

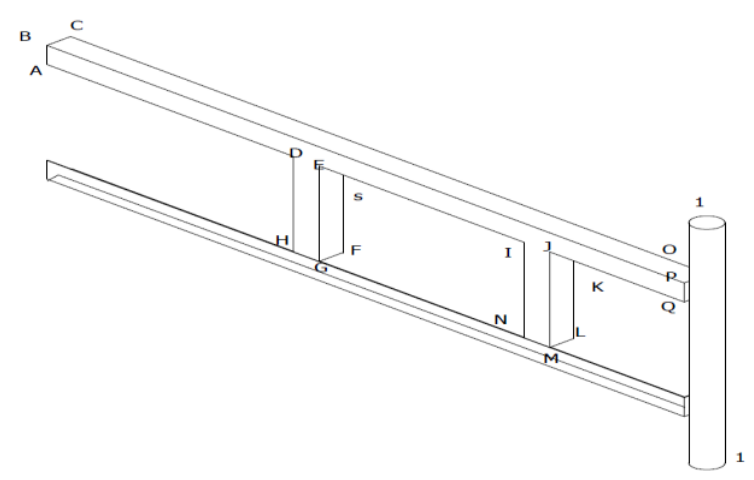

Figure 2: Schematic diagram of the main frame

Therefore, the total surface area of the main frame $\left(\mathrm{SA}_{\mathrm{m}}\right)$ was determined by adding together the areas of its surfaces and the curved surface area of the cylindrical section, as in equation (6):

$$
\begin{array}{r}
\mathrm{SA}_{\mathrm{m}}=\{4 \overline{(\mathrm{AB}} \times \overline{\mathrm{AQ}})+4(\overline{\mathrm{DE}} \times \overline{\mathrm{DH}}) 2 \\
\left.+\left(2 \pi \mathrm{rl}+2 \pi \mathrm{r}^{2}\right)\right\}
\end{array}
$$

The volume of the main frame $\mathrm{VA}_{\mathrm{m}}$ is given by:

$$
\mathrm{VA}_{\mathrm{m}}=\mathrm{SA}_{\mathrm{m}} \times \mathrm{t}_{\mathrm{m}}
$$

In (7), $t_{m}$ is the thickness of the main frame (m). The mass of the main frame, $\mathrm{MA}_{\mathrm{m}}$ is:

$$
\mathrm{MA}_{\mathrm{m}}=\mathrm{VA}_{\mathrm{m}} \times \rho_{\mathrm{m}}
$$

The weight of the main frame $\left(\mathrm{W}_{\mathrm{m}}\right)$ was determined as $184.6 \mathrm{~N}$ using equation (9).

$$
W_{m}=M_{m} \times g
$$

2.2.11 Determination of the weight of grain: The weight of the grain $\mathrm{W}_{\mathrm{g}}$ was determined as 25.34 using (10):

$$
W_{g}=M_{g} \times g
$$


Whence mass of grain is given by:

$$
\mathrm{M}_{\mathrm{g}}=\mathrm{V}_{\mathrm{g}} \times \rho_{\mathrm{g}}
$$

The actual volume of the hopper $\mathrm{V}_{\mathrm{a}}$ is determined as the volume of the trapezoidal internal section using the surface area of the trapezoid and its thickness $t_{i}$ thus:

$$
\mathrm{V}_{\mathrm{a}}=\frac{1}{2}(\mathrm{a}+\mathrm{b}) \mathrm{h} \times \mathrm{t}_{1}
$$

\subsubsection{Determination of the maximum bending} moment: Figure 3 shows the load distribution on the driving shaft. The maximum bending moment can be determined from the following expressions.

$$
\begin{array}{r}
\mathrm{R}_{1}+\mathrm{R}_{2}=\frac{1}{2}\left(\mathrm{~W}_{1}+\mathrm{W}_{2}+\mathrm{W}_{3}\right)+\mathrm{W}_{4} \\
+\frac{1}{2}\left(\mathrm{~W}_{1}+\mathrm{W}_{2}+\mathrm{W}_{3}\right) \\
\mathrm{R}_{1}=\mathrm{W}_{1}+\mathrm{W}_{2}+\mathrm{W}_{3}+\mathrm{W}_{4}-\mathrm{R}_{2}
\end{array}
$$

From computations, $\mathrm{R}_{1}=\mathrm{R}_{2}$

Using the method of sectioning, the following expressions were obtained for the bending moment;

$$
\begin{gathered}
\mathrm{M}_{\mathrm{b} 1}=\mathrm{R}_{1} \times 0.025 \\
\mathrm{M}_{\mathrm{b} 2}=\mathrm{R}_{1} \times 0.1-\frac{1}{2}\left(\mathrm{~W}_{1}+\mathrm{W}_{2}+\mathrm{W}_{3}\right) \times 0.075 \\
\mathrm{M}_{\mathrm{b} 3}=\mathrm{R}_{1} \times 0.175-\frac{1}{2}\left(\mathrm{~W}_{1}+\mathrm{W}_{2}+\mathrm{W}_{3}\right) \times 0.15 \\
\quad-\mathrm{W}_{4} \times 0.075
\end{gathered}
$$

The maximum value in equations (15), (16), and (17) is taken as the maximum bending moment for the shaft. From computations, the bending moments are $\mathrm{M}_{\mathrm{b} 1}=\mathrm{M}_{\mathrm{b} 3}=3.40 \mathrm{Nm} ; \mathrm{M}_{\mathrm{b} 2}=10.25 \mathrm{Nm}$. Therefore, the maximum bending moment from computations is $10.25 \mathrm{Nm}$. Where, $\mathrm{R}_{1}, \mathrm{R}_{2}$ is the Reactions at the supports; $\mathrm{W}_{1}$ is the Weight of the hopper material; $\mathrm{W}_{2}$ is the Weight of the main frame; $W_{3}$ is the Weight of grain resting on the hopper; $W_{4}$ is the Weight of grain resting on the shaft

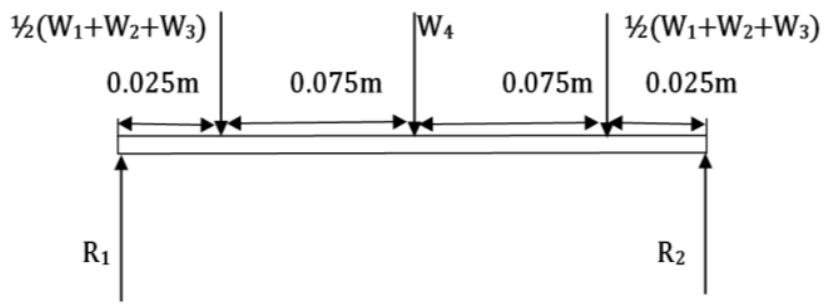

Figure 3: Load distributions on the driving shaft

2.2.13 Determination of shaft diameter: The shaft diameter was obtained as $25 \mathrm{~mm}$ using the American society of Mechanical Engineers (ASME) code equation as shown in (18).

$$
\mathrm{d}^{3}=\frac{16}{\pi \mathrm{S}_{\mathrm{a}}} \sqrt{\left(\mathrm{K}_{\mathrm{b}} \mathrm{M}_{\mathrm{b}}\right)^{2}+\left(\mathrm{K}_{\mathrm{t}} \mathrm{M}_{\mathrm{t}}\right)^{2}}
$$

In (18), $d$ is the diameter of the shaft, $M_{b}$ is the bending moment, $\mathrm{Mt}$ is the torsional moment, $\mathrm{K}_{\mathrm{b}}$ is the combined shock and fatigue factor applied to bending moment, $\mathrm{K}_{\mathrm{t}}$ is the combined shock and fatigue factor applied to torsional moment and $S_{a}$ is the allowable stress. For rotary shafts, when load is suddenly applied (minor shock); $\mathrm{K}_{\mathrm{b}}=1.5$ to $2.0 ; \mathrm{K}_{\mathrm{t}}=1.0$ to 1.5 For shafts with allowance for keyways, $\mathrm{S}_{\mathrm{a}}=84 \mathrm{MPa}$. For shafts without allowance for keyways, $S_{a}=$ 112MPa.

\subsubsection{Determination of the push force of the planter:} Figure 4 gives the free body diagram showing all the forces acting on the planter. The force required to push the planter was determined according to [3] using the following expressions.

$$
\begin{aligned}
& \sum \mathrm{H}=\mathrm{P} \cos \theta-\mathrm{R} \cos \emptyset-\mathrm{R}_{\mathrm{h}}=0 \\
& \sum \mathrm{V}=\mathrm{R} \sin \emptyset-\mathrm{P} \cos \theta-\mathrm{W}=0
\end{aligned}
$$

From equation (19),

$$
P=\frac{R \cos \emptyset+R_{h}}{\cos \theta}
$$

Substituting equation (21) into equation (20),

$$
\mathrm{R}=\frac{\mathrm{R}_{\mathrm{h}} \tan \theta+\mathrm{W}}{(\operatorname{Sin} \varnothing-\cos \varnothing \tan \theta)}
$$

In (19) to (22), $P$ is the planter push force; $R_{h}$ is the Horizontal soil resistance force; $\mathrm{R}$ is the soil frictional resistance force; $\Phi$ is the angle of friction; $\theta$ is the angle between planter handle and the horizontal plane; $\mathrm{W}$ is the weight of planter; $\sum \mathrm{H}$ is the sum of horizontal forces acting on the planter and $\sum$ Vis the sum of vertical forces acting on the planter

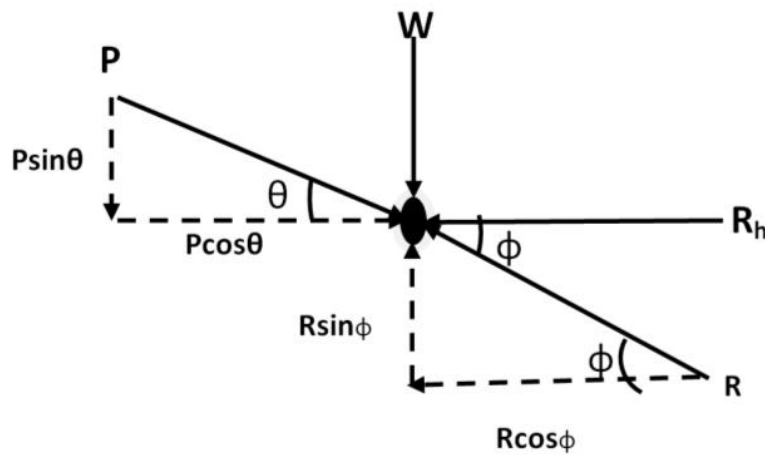

Figure 4: Free body diagram showing forces acting on the planter

2.2. 15 Determination of the maximum draft on the planter: The maximum draft on the planter is the horizontal component of push parallel to the line of motion in order to overcome the soil resistance on the planter, and is a function of the soil resistance on the machine and the area of contact of the furrow opener 
with the soil [20]. The maximum draft of the planter, $\mathrm{D}_{\max }$ was obtained as $35.784 \mathrm{~N}$ using:

$$
\mathrm{D}_{\text {Max }}=\mathrm{R}_{\mathrm{S}} \times \mathrm{A}_{\mathrm{s}} \times \mathrm{g}
$$

Here, $R_{S}$ is the soil resistance $(\mathrm{N}), A_{S}$ is the surface area of the furrow opener in contact with soil $\left[\mathrm{s}^{2}\right]$,

The surface area of furrow opener in contact with soil was estimated using:

$$
A_{s}=d \times t_{0}
$$

In (24), $d$ is the recommended depth of cut for a particular soil type $(\mathrm{m})$ and $\mathrm{t}_{0}$ is the thickness of the furrow opener $(m)$.

\subsubsection{Determination of belt size and speed of the} driving pulley: The most common systems for transmitting power from a drive to a driven shaft are belt, gear, and chain drives. But V-belt drive system which is easy to install, requires no lubrication and dampens shock load is an economical option for industrial, automotive, commercial, agricultural, and home appliance applications [18]. To select appropriate belt size for particular designs, the tensions on the belt are usually determined. In this design, the maximum tension in the belt was determined using:

$$
T=\sigma \times A_{x}
$$

Here, $\mathrm{T}$ is the maximum tension in belt $(\mathrm{N}), \sigma$ is the maximum safe stress $\left(\mathrm{N} / \mathrm{m}^{2}\right) ; A_{\mathrm{x}}$ is the cross-sectional area of the belt $\left(\mathrm{m}^{2}\right)$.

The mass of belt per meter length and the centrifugal tension of the belt were determined with equations (26) and (27) respectively.

$$
\begin{gathered}
M=\text { area } \times \text { length } \times \text { density } \\
T_{c}=m v^{2}
\end{gathered}
$$

The tensions in the tight and slack sides of the belt were determined using equation (28) according to [18],

$$
2.3 \log \frac{T_{1}}{T_{2}}=\mu . \theta
$$

Here, $T_{1}$ is the tension in the tight side of the belt $(\mathrm{N})$; $T_{2}$ is the Tension in the slack side of the belt $(\mathrm{N}) ; \mu$ is the coefficient of friction between belt and pulley and $\theta$ is the angle of contact between belt and pulley. Thus the power transmitted between the belt and the pulley $\mathrm{P}$, was determined with:

$$
P=\left(T_{1}-T_{2}\right) V
$$

The speeds of the driving and driven pulleys were also determined using the relationship between linear speed and angular speed as provided by equations (30) and (31) respectively.

$$
V=\frac{2 \pi N_{1} r}{60}
$$

$$
\frac{N_{1}}{N_{2}}=\frac{D_{2}}{D_{1}}
$$

In (30) and (31), $\mathrm{V}$ is the linear velocity in $\mathrm{m} / \mathrm{s}$; $\omega$ is the angular velocity, rad/s and $r$ is the radius of the driving pulley, $\mathrm{m} . \mathrm{N}_{1}$ is the speed of the driving pulley (rpm); $\mathrm{N}_{2}$ is the speed of the driven pulley (rpm); $\mathrm{D}_{2}$ is the diameter of driven pulley, $m$ while $D_{1}$ is the diameter of driving pulley, $\mathrm{m}$.

According to [21] narrow $v$ belts are suitable for small loads of 100 to $300 \mathrm{~N}$, and this is applicable for this design. From design calculations, the maximum tension in the belt was $262.5 \mathrm{~N}$. The length of the belt used in this design was determined as $1.7 \mathrm{~m}$ with the expression given by equation (32).

$$
L_{o}=2 C+1.57\left(D_{2}+D_{1}\right)+\frac{\left(D_{2}-D_{1}\right)^{2}}{4 C}
$$

Here, $L_{o}$ is the Length of belt, $\mathrm{m} ; \mathrm{D}_{2}$ is the diameter of big pulley $=0.20 \mathrm{~m} ; \mathrm{D}_{1}$ is the diameter of small pulley $=0.15 \mathrm{~m}$; $\mathrm{C}$ is the distance between the two pulleys $=$ $0.6 \mathrm{~m}$.

2.2.17 Determination of number of seed cells: Seed cells are the holes or spaces or grooves depending on the design in which the seeds are collected and passed through the chute for planting. Intra row spacing for maize is $30 \mathrm{~cm}$. For the rotation of the seed plate to achieve this, the diameter of the seed plate was designed using the formula for circumference $\mathrm{C}_{\mathrm{C}}$ of a circle.

$$
\mathrm{C}_{\mathrm{C}}=2 \pi \mathrm{r}
$$

Taking the circumference of the circle as the intra row distance for maize, the diameter of the seed plate was determined as $10 \mathrm{~cm}$ using equation (33). The number of seed cells $\mathrm{N}_{\mathrm{sc}}$ was determined using [22]:

$$
N_{s c}=\frac{\pi \mathrm{D}}{\mathrm{IZ}}
$$

In (34), D is the diameter of the ground wheel ( $m$ ), $Z$ is the intra row distance $(\mathrm{m})$ and $\mathrm{I}$ is the speed ratio. From computations, the number of seed cells is approximately 3 cells. The average number of seeds planted per stand was observed to be two seeds per stand during the field test.

\subsection{Construction}

The construction of the planter was done at Magnus Fabrication Workshop located in Nsukka, Enugu State, Nigeria. The 2D and 3D drawings of the planter are shown in Figure 5. For ease of construction, cost and readily available materials all component parts are made from mild steel. The hopper was constructed with $3 \mathrm{~mm}$ thickness mild steel sheet. The mainframe was constructed with $30.2 \times 30.2 \times 3 \mathrm{~mm}$ angle iron to 
provide the required strength and rigidity. The seed plate was constructed with $6 \mathrm{~mm}$ thickness mild steel sheet metal and diameter of $10 \mathrm{~mm}$. The front (traction wheel) was made from sheet metal of $6 \mathrm{~mm}$ thickness to enable proper traction. The hopper and handles were fastened to the mainframe by $17 \mathrm{~mm}$ bolts and nuts to enable easy detachment of the various component parts of the planter. The total cost of construction of the planter was twenty-eight thousand naira only as at August, 2015. Figure 5 shows 2D and 3D drawings of the planter while Figure 6 shows a picture of the completed planter.

\subsection{Test Procedure}

Preliminary test mainly to ascertain that the main functional parts are working as expected was carried out on a piece of land of dimensions $20 \mathrm{~m}$ by $10 \mathrm{~m}$. Ten rows were marked out on the land area with $90 \mathrm{~cm}$ inter row spacing. The planter hopper was filled with maize seeds and positioned appropriately along the rows and pushed to plant. Number of seeds dropped per planting point and seeds damaged were determined by visual observation. Time of operation was measured using a stop watch.

\section{RESULTS AND DISCUSSION}
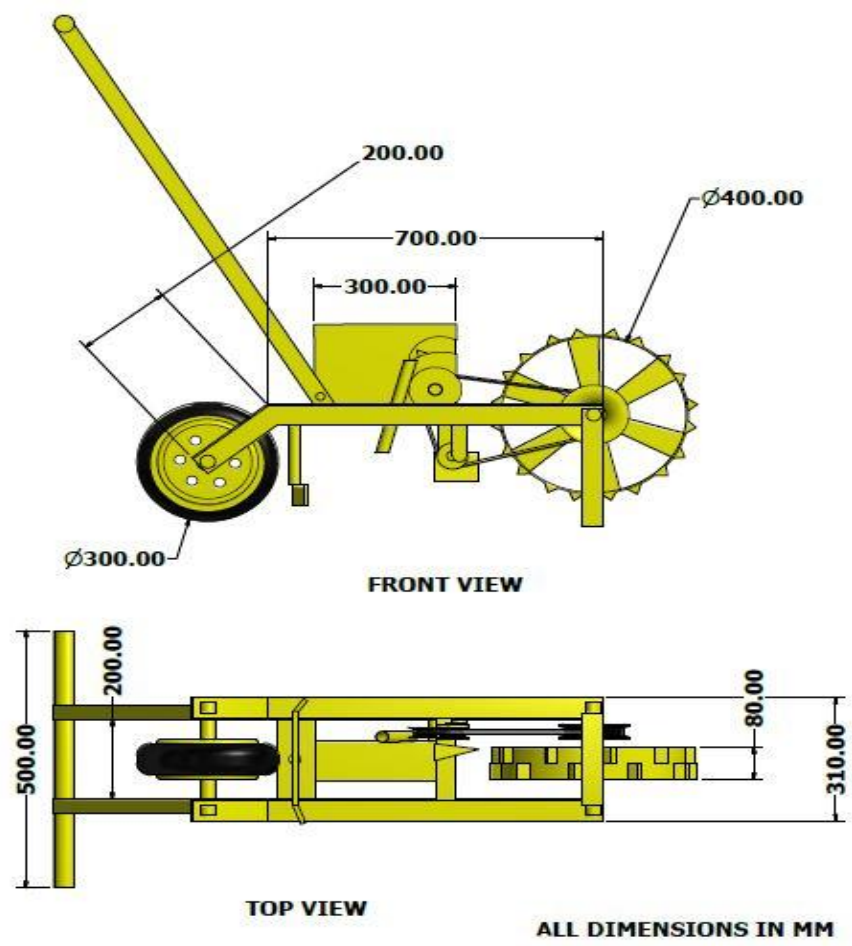

The picture of the finished planter is as shown in Figure 6. Planting tests were carried out to ascertain that the main functional parts are working as expected and it was observed that the planter could successfully plant an average of two seeds per point. The metering mechanism could successfully pick the required number of seeds from the hopper; deliver them into the chute through which the seeds are dropped along the rows at about $30 \mathrm{~cm}$ intra row spacing. The ground wheel transmitted power to the metering device through the pulley and belt system.

\subsection{Determination of the field efficiency}

The field efficiency of the planter was determined as 71.86\% using:

$$
\mathrm{y}_{\mathrm{f}}=\frac{\mathrm{T}_{\mathrm{a}}}{\mathrm{T}_{\mathrm{t}}} \times 100
$$

Here, $T_{a}$ is the time taken for actual planting operation; $T_{t}$ is the total time taken.

\subsection{Determination of actual field capacity}

The actual field capacity, $\mathrm{y}_{\mathrm{f}}$ is a function of the theoretical field capacity and field efficiency. The actual field capacity was determined as $0.27 \mathrm{ha} / \mathrm{h}$ using:

$$
\mathrm{\eta}_{\mathrm{f}}=\frac{\boldsymbol{A}_{\boldsymbol{c}}}{\boldsymbol{T}_{\boldsymbol{t}}}
$$

$A_{c}$ is the area covered during operation (ha).

Figure 5: 2D and 3D drawings of the planter 


\subsection{Determination of the planting time per hectare}

The time, $\mathrm{T}$ required to plant one hectare of farmland was determined as 3.7 hours using:

$$
T=\frac{\mathrm{D}}{\mathrm{V}}
$$

Here, D is the distance covered during operation $(\mathrm{km})$ and $V$ is the speed of operation $(\mathrm{km} / \mathrm{hr})$.

\subsection{Determination of the metering efficiency}

The metering efficiency of the planter was $88.94 \%$ determined using:

$$
M E=\frac{\mathrm{T}_{\mathrm{s}}-\mathrm{T}_{0}}{\mathrm{~T}_{\mathrm{s}}} \times 100
$$

$M E$ is the metering efficiency of the planter, \%; $\mathrm{T}_{\mathrm{s}}$ is the total number of stands in the tested farmland while $T_{0}$ is the total number of stands with no seed in the tested farmland

\subsection{Determination of percentage seed damage}

Percentage seed damage was determined as $1.71 \%$ using equation (39):

$$
S D=\frac{T n s b}{T n s p}
$$

Where :S D is the percentage seed damage; Tnsb is the total number of seeds broken; Tnsp is the total number of seeds planted

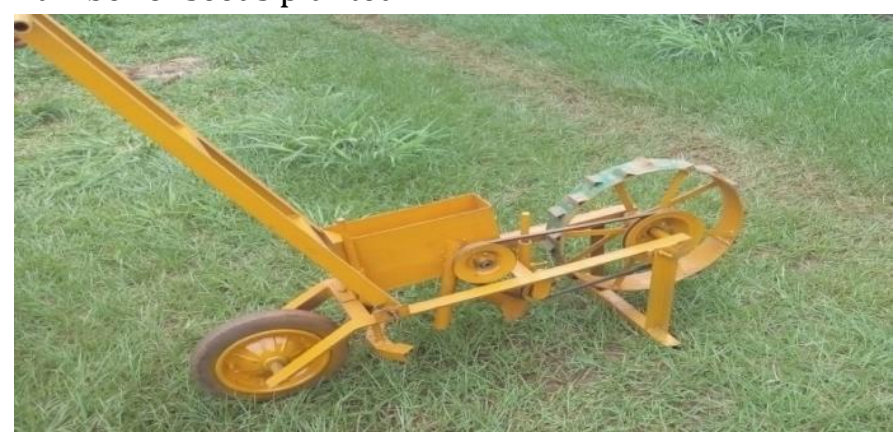

Figure 6: Picture of the completed planter

\section{CONCLUSION}

A vertical plate maize seed planter which is adapted for gardens and small holder farmers has been designed, constructed and tested. The planter could plant an average of two seeds per point. It is simple, cheap and does not require any special skill to operate. The field test results showed that the planter has a metering efficiency of $88.94 \%$, effective field capacity of $0.27 \mathrm{ha} / \mathrm{hr}$ and field efficiency of $71.86 \%$. The time required to plant one hectare of farmland was determined as 3.7 hours and percentage seed damage was determined as $1.71 \%$.This planter is economical and can be adopted for maize planting by small holder farmers.

\section{REFERENCES}

[1] IITA, "Maize," A publication of International Institute of Tropical Agriculture: Research to Nourish Africa. Ibadan, Oyo State, Nigeria. http://www.iita.org/maize, 23 March 2016., 2016.

[2] Olajide, O. G. and Manuwa, S. I., "Design, Fabrication and Testing of a Low-cost Row-Crop Planter for Peasant Farmers " Proceedings of the International Soil Tillage Research Organisation (ISTRO) Nigeria Symposium, Akure 2014 November 3 - 6, Akure, Nigeria, pp. 94-100, 2014.

[3] Ikechukwu, A., Ibukun, B., and Ikechukwu, C. U., "Design and Fabrication of a Single Row Maize Planter for Garden Use" Journal of Advancement in engineering technology, Issue 1/ vol 2, pp 1-7, 2014.

[4] Oduma, O., Ede, J. C., and Igwe, J. E., "Development and Performance Evaluation of a manually operated Cowpea Precision Planter," International Journal of Engineering and Technology, Volume 4 No. 12, December, 2014, pp. 4-7, 2014.

[5] Bashiri, M., Ode, D. A., and Ogwuche, E. U., "Development of a hand planter " JORIND 11(2) December, 2013; pp. 1-6, 2013.

[6] Adisa, A. F. and Braide, F. G., "Design and Development of Template Row Planter," Transnational Journal of Scuience and Technology, Vol. 2, No. 7, pp. 2-6, 2012.

[7] Gupta, C. P. and T.Herwanto, "Design and development of a direct paddy seede " Agricultural Mechanization in Asia, Africa and Latin America, vol. 23(1), pp. .23-27, 1992.

[8] Kumar, K., Naaresh, N. K., and Ojha, T. P., "Design, construction and performance of a manuallyoperated seeding attachment for an animal drawn cultivator " Agricultural Mechanization in Asia, Africa and Latin America, vol. 17(2), pp. 35-38, 1986.

[9] Murray, J. R., Tullberg, J., and Basnet, B. B., "Planters and their components; types, attributes, functional requirements, classification and description," Australian center for international agricultural research (ACIAR) monograph 121, 2006.

[10] Townsend, J. S. and Bethge, J. M., "Furrow opener for proper seed and fertiliser placement in no-till " ASAE Paper No. 84-151 Am. Soc. Agr. Eng. St Joseph, MI, 2011.

[11] Khan, A. A., "Preplant physiological seed conditioning " Hort. Rev. 13: 131-181, 2008.

[12] Jayan, P. R. and Kumar, V. J. F., "Planter design in relation to the physical properties of seeds " Journal of Tropical Agriculture, 42(1-2), pp. 69-71, 2004.

[13] Gray, A. G. and MacIntyre, D., "Soil penetration by disc coulters of direct drills," The Agricultural Engineer, 38(4):106-109, 2012. 
[14] Norris, C. P., "Performance of some different types of peanut/maize planters in NQ," Proc. Conf. on Agric. Eng., Armidale. I.E. Aust. Nat. Conf. Publ. No 82/8: 149-154, 1982.

[15] Fenner, M., "Environmental influences on seed size and composition," Hort. Rev. 13, 183-213, 1992.

[16] Butzen, S. and Hall, T., "Planter Maintenance and Calibration.," 2014.

[17] Murray, J. R., N.Tullberg, J., and Basnet, B. B., "Planters and their components; types, attributes, functional requirements, classification and description," Australian center for international agricultural research (ACIAR) monograph 121., 2006.
[18] Khurmi, R. S. and Gupta, J. K., "A Textbook of Machine Design " 14th revised edition. Chapters 2, 14 and 18, 2005.

[19] Bharat, M. R. and Sidharth, D., "Tire modelling for rolling resistance " Master's Thesis in automotive engineering, vehicle dynamics group, Chalmers University of technology, Sweden., p. 24, 20142014.

[20] Gbabo, A., "Design and construction of a two-row cowpea and maize planter " Maintenance and Repair Unit, Agricultural Engineering Section, National Cereals Research Institute, Badeggi., 1998.

[21] PIC-Design, "Interactive catalog," CAD. ecommerce, Vol. 3, Section 5, pp 1-42, 2010.

[22] Kepner, R. A., Bainer, R., and Berger, E. L., "Principle of Farm machinery," AVI Publishing Company, Inc. West Port, Connecicut, 1978. 